\title{
Variability of nodulation traits in Andean and Mesoamerican common bean gene pools
}

\author{
Adriano Moreira Knupp ${ }^{(1)}$, Enderson Petrônio de Brito Ferreira(1) and Adelson Paulo Araújo(2) \\ (1)Embrapa Arroz e Feijão, Rodovia GO-462, Km 12, CEP 75375-000 Santo Antônio de Goiás, GO, Brazil. E-mail: \\ adriano.knupp@embrapa.br, enderson.ferreira@embrapa.br (2)Universidade Federal Rural do Rio de Janeiro, Departamento de Solos, \\ Rodovia BR-465, Km 7, CEP 23890-000 Seropédica, RJ, Brazil. E-mail: aparaujo@ufrrj.br
}

\begin{abstract}
The objective of this work was to evaluate the genotypic diversity for nodulation in common bean (Phaseolus vulgaris) genotypes of Andean and Mesoamerican gene pools present in the core collections of Embrapa, in Brazil. Evaluations were carried out in two stages: the first one with 879 genotypes, taking the cultivar 'Ouro Negro' as reference; and the second one with 116 genotypes with greater nodulation, to identify those showing stability in nodulation in the two stages. Rhizobium strains were inoculated in pre-germinated common bean seed. Plants received weekly a nutrient solution without $\mathrm{N}$, and nodulation was evaluated 35 days after planting. The percentage of genotypes that exceeded the reference cultivar was $22 \%$ for number of nodules, $46 \%$ for nodule dry weight, and $33 \%$ for one nodule dry weight. The combined analysis of data from the two evaluation phases showed wide differences among genotypes, and significant interactions between genotypes and stages. By the orthogonal contrasts analysis, the Mesoamerican genotypes showed a greater nodulation than the Andean ones. In both stages, twenty-six more stable genotypes were identified, most of them belonging to the Mesoamerican gene pool. There is a large variability in nodulation traits among the common bean genotypes present in the core germplasm collections of Embrapa, which suggests that there are genotypes with improved nodulation.
\end{abstract}

Index terms: Phaseolus vulgaris, biological nitrogen fixation, diversity, germplasm bank.

\section{Variabilidade das características de nodulação em feijoeiro- comum dos conjuntos gênicos andino e mesoamericano}

Resumo - O objetivo deste trabalho foi avaliar a diversidade genotípica quanto à nodulação em genótipos de feijoeiro-comum (Phaseolus vulgaris) pertencentes aos conjuntos gênicos andino e mesoamericano presentes nas coleções nucleares da Embrapa, no Brasil. As avaliações foram realizadas em dois estágios: o primeiro com 879 genótipos, tendo-se a cultivar 'Ouro Negro' como referência; e o segundo, com 116 genótipos de maior nodulação, para identificar aqueles com estabilidade de nodulação nos dois estágios. Estirpes de Rhizobium foram inoculadas em sementes de feijão pré-germinadas. As plantas receberam, semanalmente, uma solução nutritiva isenta de $\mathrm{N}$, e a nodulação foi avaliada 35 dias após o plantio. O percentual de genótipos que superaram a cultivar-referência foi de: $22 \%$, quanto ao número de nódulos; $46 \%$, quanto à massa de matéria seca de nódulos; e 33\%, quanto à massa de matéria seca de um nódulo. A análise conjunta dos dados das duas fases de avaliação identificou amplas diferenças entre genótipos e interações significativas entre genótipos e estágios. $\mathrm{Na}$ análise de contrastes ortogonais, os genótipos mesoamericanos apresentaram maior nodulação do que os andinos. Foram identificados 26 genótipos mais estáveis nos dois estágios, a maioria deles pertencente ao conjunto gênico mesoamericano. Há uma ampla variabilidade em caracteres relacionados à nodulação entre os genótipos de feijoeiro presentes nas coleções nucleares da Embrapa, o que é indício de que há genótipos com maior nodulação.

Termos para indexação: Phaseolus vulgaris, fixação biológica de nitrogênio, diversidade, banco de germoplasma.

\section{Introduction}

The genetic diversification of common bean (Phaseolus vulgaris L.) had two main centers of domestication, the Andean e Mesoamerican (Bitocchi et al., 2013) ones, which can be distinguished by plant morphology (Singh et al., 1991; Rana et al., 2015), as well as by molecular approaches (Bitocchi et al., 2013; Gaut, 2014). The Mesoamerican gene pool consists of small seed, with 100-seed weight of less than $25 \mathrm{~g}$, and 
all type of plant growth habits, while the Andean gene pool have middle seed, whose 100 -seed weight ranges from 25 to $40 \mathrm{~g}$, and big seed with 100 -seed weight above $40 \mathrm{~g}$, with plants growth habit types I, II, and III (Singh et al., 1991). Mesoamerican materials provided the genetic basis of most Brazilian commercial cultivars (Blair et al., 2013), and most of the landrace genotypes (Burle et al., 2010).

Due to an incomplete reproductive isolation, most crosses between the Mesoamerican and Andean gene pools generate F1 unfeasible families (Hannah et al., 2007). Epistasis for the pod number, seed number, and seed weight was observed in progenies derived from crosses between the Andean and Mesoamerican genotypes, and it is suggested as one of the determining factors in the failure of crosses between genotypes from different origins (Moreto et al., 2012). Therefore, the genetic variability from one cultivated gene pool has a limited use for improving quantitative traits in the other gene pool. As a consequence, the access to the available diversity within each of these two gene pools is required for identification of the genotypes with desirable alleles to be introduced into breeding programs (Singh, 2001; Rana et al., 2015).

Common bean is a leguminous plant that can obtain $\mathrm{N}$ through symbiosis with rhizobia, although such symbiosis is often considered insufficient to fulfill the entire crop demand (Graham et al., 2003; Fageria et al., 2014). Since common bean domestication and selection may have resulted on loss of genetic diversity over time (Singh, 2001), its ability to fix $\mathrm{N}_{2}$ may also have been reduced, particularly across Brazil breeding efforts which have been conducted using $\mathrm{N}$ fertilization. The genetic diversity in collections conserved in the gene banks has helped breeders to identify eligible genotypes for potential sources of desirable genes (Blair et al., 2010; Rana et al., 2015), and the use of wild and weed common bean germplasm can offer a great potential to enhance the variation in the crop (Araújo et al., 1998; Acosta-Gallegos et al., 2007). However, since the selection of lines derived from crosses between the Andean and Mesoamerican gene pools of $P$. vulgaris is reported as problematic, the wild germplasm from within the same gene pool should be prioritized in breeding over the wild lines from the other gene pool (Acosta-Gallegos et al., 2007).

Nitrogen fertilization is one of the main factors inhibiting the development of symbiotic process in legumes, thus plant assessments under conditions of low $\mathrm{N}$ availability are recommended to provide an appropriate selection pressure for highly effective nodulation and $\mathrm{N}_{2}$ fixation (Kraiser et al., 2011). Nodulation is the main plant trait related to the ability for high $\mathrm{N}_{2}$ fixation in common bean (Graham et al., 2003; Lazali et al., 2016), and increased nodulation is an important and heritable component of symbiosis for selection of bean lines capable of fixing more $\mathrm{N}_{2}$ (Pereira et al., 1993).

Many efforts have been made for screening new microorganisms with improved symbiotic capacity, but the assessment of genotypic variation in host plant also assumes a paramount importance (Graham et al., 2003; Akter et al., 2014). The exploitation of plant diversity by identifying genotypes presenting a high nodulation potential is advised for choosing parents for breeding programs aimed to increase the biological $\mathrm{N}_{2}$ fixation of common bean. A large-scale phenotypic characterization provides important information for breeders (Rana et al., 2015), and the present study comprises one of the most extensive investigations focusing on nodulation traits in Brazilian common bean germplasm collections.

The objective of this work was to evaluate the genotypic diversity for nodulation in common bean genotypes of the Andean and Mesoamerican gene pools present in the core collections of Embrapa, in Brazil

\section{Materials and Methods}

Genotypes belonging to two core collections of Embrapa Arroz e Feijão were evaluated in response to inoculation of strains that are currently recommended as inoculants for the common bean crop: Rhizobium tropici Semia 4077 (Ciat-899) and Semia 4088; and $R$. freirei Semia 4080. A group of 879 genotypes was evaluated, out of which 261 from the Mexico core collection, and 618 from the International Center of Tropical Agriculture (Ciat, Colombia) core collection. Mexico's core collection consists mostly of materials from pure lines, obtained by Embrapa Arroz e Feijão from the United States Department of Agriculture (USDA). In both collections, there were Mesoamerican and Andean materials. Both collections are currently kept in the Banco Ativo de Germoplasma de Feijão (Phaseolus vulgaris) (active common bean germplasm bank) at Embrapa.

The experiments were conducted in two stages in a greenhouse at Embrapa Arroz e Feijão, in

Pesq. agropec. bras., Brasília, v.52, n.4, p.252-260, abr. 2017 DOI: 10.1590/S0100-204X2017000400005 
Santo Antônio de Goiás, GO, Brazil. The first stage consisted of screening 879 genotypes in greenhouse, in a randomized block design with three replicates, in eight successive sowings, from September 2011 to March 2012. In each of the eight sowings, 'Ouro Negro' was the cultivar used as reference, due to its ability to fix $\mathrm{N}_{2}$ (Henson et al., 1993). In the second stage, 116 genotypes with a greater nodulation, selected at the first stage, were evaluated to identify those showing nodulation stability in the two phases. The experiment was carried out in a greenhouse, in a randomized block design with three replicates, from August to October 2012.

In both stages, seed were taken from a cold chamber at $-10^{\circ} \mathrm{C}$, and then they were scarified, packed in germitest paper humidified with sterile water, and kept in a growth chamber at $24^{\circ} \mathrm{C}$. After radicle protrusion, five seed per pot were planted in $3 \mathrm{~L}$ pots filled with sterile sand and vermiculite (2:1 v:v). Seven days after planting (DAP), seedlings were thinned to three plants per pot. Each plant was treated with $1 \mathrm{~mL}$ of a mixture of three commercial Rhizobium strains grown in YM culture (Vincent, 1970), with $10^{9}$ cells $\mathrm{mL}^{-1}$. Once a week, $200 \mathrm{~mL}$ per pot of Norris nutrient solution without $\mathrm{N}$ was added, and irrigation was performed with sterile water every two days. During the development period, plants were kept in a greenhouse, where the temperature was monitored and regulated with a shading system. Plants were harvested at 35 DAP, and roots were separated from e shoots and carefully washed in running water. Nodules were detached and counted, oven-dried $\left(65^{\circ} \mathrm{C}\right.$ for 48 hours $)$, and weighed. The one-nodule dry weight was obtained by the ratio between the dry weight and the number of nodules.

Data obtained from 'Ouro Negro', in each of the eight sowings, were subjected to the analysis of variance, in order to evaluate the experimental uniformity across sowing dates, which was confirmed by the lack of sowing effects on nodule traits. Further, the analysis of variance was performed for data of the eight sowings of nodulated genotypes and the cultivar 'Ouro Negro'. Tukey's test, at 5\% probability was used for grouping genotypes in nodulation classes. A scatter diagram displaying nodule dry weight and the number of nodules was drawn, and 116 genotypes were selected for the second evaluation. Based on information such as the genotype origin and the seed size, obtained from the databases of Ciat and Grin-Global (Global Plant
Genbank Information Management System - USDA), the 116 genotypes were further related to the Andean or Mesoamerican gene pools.

In the second stage, for sowing and plant development, the same procedures previously described for the assessment of 879 genotypes were adopted. Data obtained from 116 genotypes were joined to the data of the same genotypes obtained in the first stage, and the analysis of variance was performed, considering a double factorial between stage and genotype; means of each stage of evaluation were compared by Student $t$ test (LSD), at 5\% probability. This combined analysis was used as an indicator of stability of materials with high nodulation in both evaluations. Further, the analysis of variance was performed for each stage separately, and the sums of squares were rearranged to perform an orthogonal contrast between the genotypes of the two gene pools by the $\mathrm{F}$ test. With the average values of nodule dry weight and the number of nodules obtained for 116 genotypes, in the two stages of evaluation, a scatter diagram was carried out for selection of the most promising genotypes.

\section{Results and Discussion}

In the first stage of evaluation, from a total of 879 evaluated genotypes, 686 ones presented some nodulation. These 686 nodulated genotypes and the reference cultivar 'Ouro Negro' showed large difference among genotypes (Table 1). The number of nodules per plant ranged from 2 to 646, nodule dry weight ranged from 1 to $601 \mathrm{mg}$ per plant, and one nodule dry weight ranged from 0.10 to $13.24 \mathrm{mg}$ (Figure 1). Differences between common bean genotypes for nodulation traits are often observed in greenhouse experiments, such as those reported by Akter et al. (2014) and Farid \& Navabi (2015), who reported a similar magnitude of variation to that observed in the present work.

Considering that a strong nodulation is associated with improved symbiotic $\mathrm{N}_{2}$ ability in common bean (Graham et al., 2003; Drevon et al., 2011; Lazali et al., 2016), the extensive evaluation of a wide number of accesses allows of the use of nodulation data as a faster way to genotype selection. Additionally, differences in shoot dry weight might not have a strict adherence to $\mathrm{N}_{2}$ symbiotic rates, particularly in weedy genotypes that can show a poor adaptation to specific growth conditions, and sensitivity to photoperiod (Araújo et al., 1998). 
The genotypes were allocated in nodulation classes, as follows: 148 genotypes (22\%) were placed in higher classes than the reference cultivar 'Ouro Negro', for the number of nodules; 316 genotypes (46\%) were higher than the reference cultivar for nodule dry weight (Figure 1); and 225 genotypes (33\%) fall above 'Ouro Negro' for one nodule dry weight. From the scatter diagram of nodule dry weight and the number of nodules of the 686 nodulated genotypes, 116 genotypes with improved nodulation could be identified (Figure 2). Among these 116 genotypes, 53 Mesoamerican and 61 Andean genotypes were identified; however, for two genotypes, information was unavailable.

The orthogonal contrast analysis between the two gene pools showed that, in the second stage of evaluation, the Mesoamerican gene pool showed both higher nodule dry weight and one nodule dry weight than the Andean gene pool, whereas, in the first stage, the number of nodules and nodule weights were similar for both gene pools (Table 2). Akter et al. (2014) also found a higher nodulation ability in Mesoamerican than in Andean genotypes, whereas Farid \& Navabi (2015) found a greater number of nodules and nodule weights in Andean genotypes; however, nodules were more active in Mesoamerican genotypes. By the magnitude of the mean squares of variation sources estimated in the analysis of variance, it was not possible to state one of these two gene pools as showing larger genotypic variability for nodulation traits.

Evaluating 158 common bean genotypes, Rodiño et al. (2011) have distinguished groups with large nodules, although they were few in number, which showed plants with higher shoot mass, and genotypes with small and numerous nodules, but with plants with lower shoot growth. Larger and heavier nodules are considered more important than a high number of

Table 1. Analysis of variance (values of mean square) of the number of nodules, nodule dry weight, and one nodule dry weight of 686 common bean genotypes, and the reference cultivar 'Ouro Negro', in eight sowings of bean genotypes in greenhouse.

\begin{tabular}{lrccc}
\hline $\begin{array}{l}\text { Source of } \\
\text { variation }\end{array}$ & DF & $\begin{array}{c}\text { Number of } \\
\text { nodules }\end{array}$ & $\begin{array}{c}\text { Nodule dry } \\
\text { weight }\end{array}$ & $\begin{array}{c}\text { One nodule dry } \\
\text { weight }\end{array}$ \\
\hline Block & 2 & 13091.89 & $20890.40^{*}$ & 0.16 \\
Genotype & 686 & $7050.63^{* * *}$ & $35641.41^{* * *}$ & $2.03^{* * *}$ \\
Residue & 1372 & 5854.00 & 6487.37 & 0.57 \\
\hline CV (\%) & & 55.77 & 48.52 & 57.90 \\
\hline
\end{tabular}

*,***Significant at 5 and $0.1 \%$ probability, respectively, by the $\mathrm{F}$ test. them, since many small nodules might not reflect a good $\mathrm{N}_{2}$ fixation ability (Pereira et al., 1993). Moreover, the occupation of nodules by active bacteroids is also
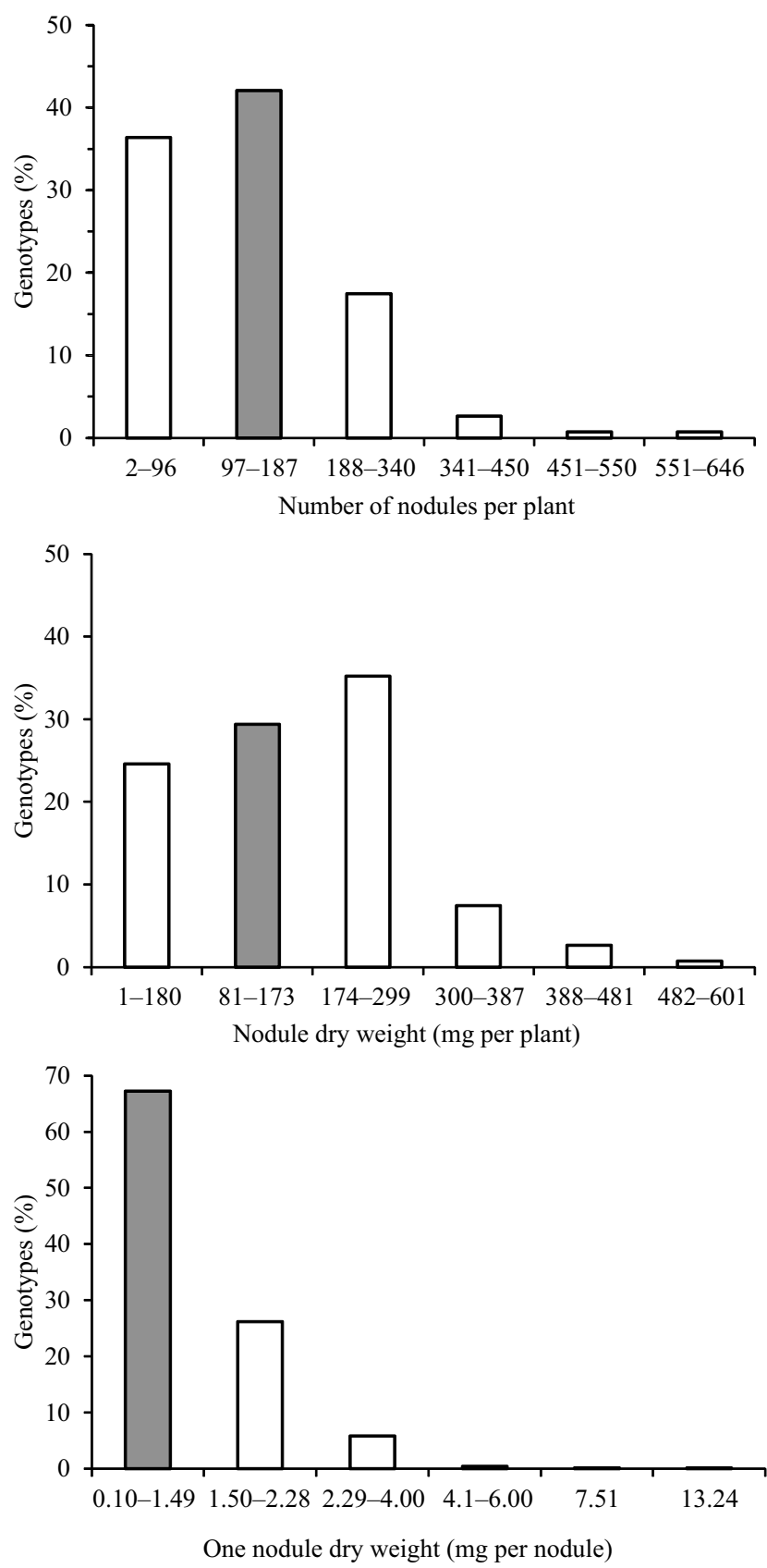

Figure 1. Percentage distribution of 686 nodulated common bean genotypes, according to the number of nodules per plant, nodule dry weight per plant, and one nodule dry weight, in greenhouse experiments; the gray column signals the group including the reference cultivar 'Ouro Negro'. The distribution classes were defined by Tukey's test, at 5\% probability. 
very important for the symbiosis (Arthikala et al., 2014). The number of nodules and the nodule dry weight are phenotypic characteristics considered as representatives for identifying quantitative trait loci (QTL) for biological N fixation (Santos et al., 2013). In some limiting conditions for plant growth, such as
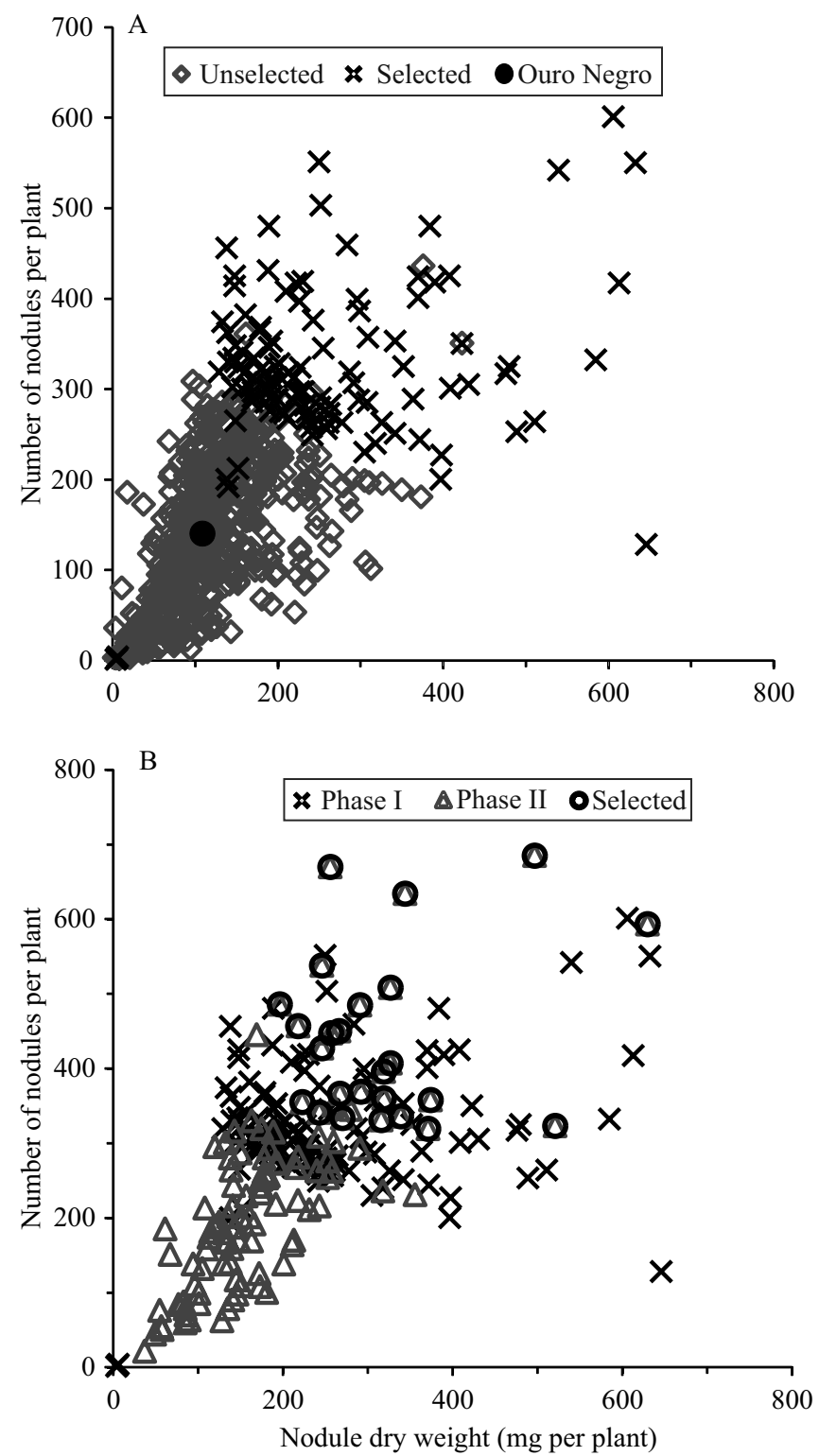

Figure 2. Number of nodules and nodule dry weight of 686 nodulated common bean genotypes in greenhouse experiments. A, The reference cultivar 'Ouro Negro', and the 116 genotypes selected for the second stage of evaluation were detached. B, Distribution of the number of nodules and the nodule dry weight of 116 common bean genotypes, in two stages of evaluation; the most promising genotypes were detached as selected ones.
$\mathrm{P}$ deficiency, large individual nodules can compensate for the decreased number of nodules (Lazali et al., 2016), underlying the relevance of nodule weight as a parameter of evaluation. Notwithstanding, the relationship between nodule size and $\mathrm{N}_{2}$ fixation ability stands to be clearly established on common bean.

The combined analysis of variance showed significant differences for nodule traits among the 116 genotypes evaluated in two stages, as well as a significant interaction between genotypes and the evaluation stage (Table 3 ). The nodulation of genotypes was broadly lower in the second stage (Figure 2); however, the Andean genotypes showed a stronger reduction in the number and weight of nodules in this stage than the Mesoamerican genotypes (Table 2), suggesting a higher stability of nodulation in Mesoamerican genotypes.

In common bean breeding programs, the evaluation season is a major factor influencing the interaction between genotype and environment (Pereira et al., 2011). The time of sowing is considered an unpredictable environmental factor, and its effect has been most commonly assessed under field conditions (Rodiño et al., 2011; Torga et al., 2013). Considering that the present work took place in greenhouse conditions, the significant interaction between genotype and evaluation stage (Table 3) may have been affected by subtle environmental variations between the two stages. Terán \& Singh (2009) also detected the interaction between year of sowing and different screening methods in the identification of bean genotypes resistant to white mold in greenhouse experiments.

The magnitude of the interaction between genotype and evaluation stage for nodule traits (Table 3) reinforces the adequacy of choosing the most stable genotypes across environments. By the combined analysis of data obtained from 116 genotypes and the scatter diagram of nodule dry mass and number of nodules (Figure 2), 26 promising genotypes could be selected for their high nodulation and repeatability in the two stages(Table 4). Out of these 26 genotypes, 10 belong to the Andean gene pool, 15 belong to the Mesoamerican gene pool, and one could be related to any gene pool (Table 5). Most of these genotypes had black (8) or red tegument (5). Indeterminate growth habit prevailed, appearing in 19 genotypes.

The diversity of response obtained in the present study through Rhizobium inoculation shows the relevant 
Table 2. Contrasts between Andean and Mesoamerican groups of common bean genotypes for the number of nodules, nodule dry weight, and one nodule dry weight, in two evaluation stages in greenhouse ${ }^{(1)}$.

\begin{tabular}{lccccccc}
\hline Group & \multicolumn{4}{c}{ Stage I } & & \multicolumn{3}{c}{ Stage II } \\
\cline { 2 - 3 } & $\begin{array}{c}\text { Number of nodules } \\
\text { per plant }\end{array}$ & $\begin{array}{c}\text { Nodule dry weight } \\
\text { (mg per plant) }\end{array}$ & $\begin{array}{c}\text { One nodule dry } \\
\text { weight }(\mathrm{mg})\end{array}$ & & $\begin{array}{c}\text { Number of nodules } \\
\text { per plant }\end{array}$ & $\begin{array}{c}\text { Nodule dry weight } \\
\text { (mg per plant) }\end{array}$ & $\begin{array}{c}\text { One nodule dry } \\
\text { weight (mg) }\end{array}$ \\
\hline Mesoamerican & $245 \mathrm{a}$ & $319 \mathrm{a}$ & $1.47 \mathrm{a}$ & & $188 \mathrm{a}$ & $264 \mathrm{a}$ & $1.46 \mathrm{a}$ \\
Andean & $267 \mathrm{a}$ & $320 \mathrm{a}$ & $1.43 \mathrm{a}$ & & $193 \mathrm{a}$ & $231 \mathrm{~b}$ & $1.25 \mathrm{~b}$ \\
\hline
\end{tabular}

${ }^{(1)}$ Means followed by equal letters, in the columns, do not differ, by the F test, at 5\% probability. Mesoamerican and Andean groups represent the averages of 53 and 61 genotypes, respectively.

Table 3. Analysis of variance (values of mean square) of nodulation traits of 116 common bean genotypes, in two evaluation stages in greenhouse.

\begin{tabular}{lrccc}
\hline Source of variation & DF & Number of nodules & Nodule dry weight & One nodule dry weight \\
\hline Block & 2 & $4.55^{*}$ & $5.26^{* * *}$ & 0.04 \\
Genotype & 115 & $4.43^{* * *}$ & $4.70^{* * *}$ & $0.73^{* * *}$ \\
Phase & 1 & $72.80^{* * *}$ & $89.30^{* *}$ & $51.46^{* * *}$ \\
Genotype x phase & 115 & $3.16^{* * *}$ & $3.52^{* * *}$ & $0.72^{* * *}$ \\
Residue & 462 & 1.14 & 1.06 & 0.11 \\
\hline Coeficient of variation $(\%)$ & 47.46 & 36.25 & 28.32 \\
\hline
\end{tabular}

$*, * *, * *$ Significant at 5,1 , and $0.1 \%$ probability, respectively, by the $\mathrm{F}$ test.

Table 4. Number of nodules, nodule dry weight, and one nodule dry weight of the selected, promising common bean genotypes, after two evaluation stages in greenhouse ${ }^{(1)}$.

\begin{tabular}{|c|c|c|c|c|c|c|c|}
\hline \multirow[t]{2}{*}{ Genotype } & \multirow[t]{2}{*}{ Core collection } & \multicolumn{2}{|c|}{ Number of nodules per plant } & \multicolumn{2}{|c|}{ Nodule dry weight (mg per plant) } & \multicolumn{2}{|c|}{ One nodule dry weight $(\mathrm{mg})$} \\
\hline & & Stage I & Stage II & Stage I & Stage II & Stage I & Stage II \\
\hline CNF 0011234 & Ciat & $633 a$ & $497 \mathrm{a}$ & $550 \mathrm{a}$ & $685 \mathrm{a}$ & $0.89 \mathrm{a}$ & $0.73 \mathrm{a}$ \\
\hline CNF 0011559 & Ciat & $585 \mathrm{a}$ & $630 \mathrm{a}$ & $332 b$ & $593 \mathrm{a}$ & $0.57 \mathrm{a}$ & $1.05 \mathrm{a}$ \\
\hline CNF 0011239 & Ciat & $192 \mathrm{a}$ & $344 a$ & $306 b$ & $634 a$ & $1.53 \mathrm{a}$ & $0.54 \mathrm{~b}$ \\
\hline PI 209491 & Mexico & $409 a$ & $256 a$ & $301 b$ & $670 \mathrm{a}$ & $0.74 \mathrm{a}$ & $0.38 \mathrm{a}$ \\
\hline PI 387865 & Mexico & $390 \mathrm{a}$ & $327 \mathrm{a}$ & $418 \mathrm{a}$ & $508 \mathrm{a}$ & $1.02 \mathrm{a}$ & $0.64 \mathrm{~b}$ \\
\hline CNF 0011228 & Ciat & $384 a$ & $246 \mathrm{a}$ & $480 \mathrm{a}$ & $538 \mathrm{a}$ & $1.25 \mathrm{a}$ & $0.44 b$ \\
\hline CNF 0011026 & Ciat & $188 \mathrm{a}$ & 291a & $431 \mathrm{a}$ & $485 \mathrm{a}$ & $2.33 a$ & $0.60 \mathrm{~b}$ \\
\hline CNF 0011137 & Ciat & $170 \mathrm{~b}$ & $521 \mathrm{a}$ & $291 \mathrm{a}$ & $323 \mathrm{a}$ & $1.72 \mathrm{a}$ & $1.68 \mathrm{a}$ \\
\hline CNF 0011075 & Ciat & $262 \mathrm{a}$ & $266 \mathrm{a}$ & $273 b$ & $450 \mathrm{a}$ & $1.05 \mathrm{a}$ & $0.60 \mathrm{a}$ \\
\hline CNF 0011095 & Ciat & $222 \mathrm{a}$ & $196 a$ & $417 \mathrm{a}$ & $486 a$ & $1.88 \mathrm{a}$ & $0.40 \mathrm{~b}$ \\
\hline CNF 0011240 & Ciat & $226 a$ & $257 \mathrm{a}$ & $397 \mathrm{a}$ & $447 \mathrm{a}$ & $1.74 \mathrm{a}$ & $0.59 \mathrm{~b}$ \\
\hline CNF 0011028 & Ciat & $364 a$ & $327 \mathrm{a}$ & $289 \mathrm{a}$ & $407 a$ & $0.96 \mathrm{a}$ & $0.81 \mathrm{a}$ \\
\hline PI 325750 & Mexico & $218 \mathrm{a}$ & $218 \mathrm{a}$ & $288 b$ & $457 \mathrm{a}$ & $1.28 \mathrm{a}$ & $0.48 \mathrm{~b}$ \\
\hline PI 313633 & Mexico & $187 \mathrm{a}$ & $319 a$ & $299 a$ & $396 a$ & $2.09 \mathrm{a}$ & $0.75 b$ \\
\hline CNF 0011086 & Ciat & $203 a$ & $374 a$ & $275 \mathrm{a}$ & $358 \mathrm{a}$ & $1.36 \mathrm{a}$ & $1.05 \mathrm{a}$ \\
\hline CNF 0011102 & Ciat & $308 \mathrm{a}$ & $371 \mathrm{a}$ & $285 a$ & $319 a$ & $0.93 \mathrm{a}$ & $1.16 \mathrm{a}$ \\
\hline CNF 0011015 & Ciat & $178 \mathrm{a}$ & $339 a$ & $364 a$ & $336 a$ & $1.98 \mathrm{a}$ & $1.08 \mathrm{~b}$ \\
\hline PI 312031 & Mexico & $145 b$ & $319 a$ & $302 \mathrm{a}$ & $360 \mathrm{a}$ & $2.22 \mathrm{a}$ & $0.87 \mathrm{~b}$ \\
\hline CNF 0011252 & Ciat & $237 \mathrm{a}$ & $292 a$ & $267 \mathrm{a}$ & $369 a$ & $1.11 \mathrm{a}$ & $0.79 \mathrm{a}$ \\
\hline PI 309701 & Mexico & $191 \mathrm{a}$ & $267 \mathrm{a}$ & $290 \mathrm{a}$ & $366 \mathrm{a}$ & $1.43 \mathrm{a}$ & $0.74 \mathrm{~b}$ \\
\hline CNF 0011027 & Ciat & $296 \mathrm{a}$ & $280 \mathrm{a}$ & $399 a$ & $345 \mathrm{a}$ & $1.67 \mathrm{a}$ & $0.88 \mathrm{~b}$ \\
\hline CNF 0010996 & Ciat & $190 \mathrm{a}$ & $270 \mathrm{a}$ & $346 a$ & $334 \mathrm{a}$ & $1.81 \mathrm{a}$ & $0.90 \mathrm{~b}$ \\
\hline CNF 0011053 & Ciat & $231 \mathrm{a}$ & $243 \mathrm{a}$ & $297 \mathrm{a}$ & $341 \mathrm{a}$ & $1.33 \mathrm{a}$ & $0.75 b$ \\
\hline CNF 0011097 & Ciat & $278 \mathrm{a}$ & $246 \mathrm{a}$ & $263 \mathrm{a}$ & $427 \mathrm{a}$ & $1.07 \mathrm{a}$ & $0.57 \mathrm{a}$ \\
\hline PI 313495 & Mexico & $250 \mathrm{a}$ & $223 a$ & $551 \mathrm{a}$ & $355 b$ & $2.12 \mathrm{a}$ & $0.67 \mathrm{~b}$ \\
\hline CNF 0011451 & Mexico & $251 \mathrm{a}$ & $316 \mathrm{a}$ & $280 \mathrm{a}$ & $331 \mathrm{a}$ & $1.13 \mathrm{a}$ & $0.95 \mathrm{a}$ \\
\hline
\end{tabular}

(1)Means followed by equal letters, in the lines, do not differ, by Student t (LSD) test, at 5\% probability. 
Table 5. Some characteristics of the 26 most promising common bean genotypes for nodulation traits, selected after two stages of evaluation in greenhouse.

\begin{tabular}{|c|c|c|c|}
\hline Genotype & Another identification & Place of collection & Gene pool \\
\hline CNF 0011234 & G22599 & Congo & Andean \\
\hline CNF 0011559 & G2573 & Ecuador & Andean \\
\hline CNF0011239 & G23568B & Peru & Andean \\
\hline PI 209491 & G18800 & Costa Rica & Mesoamerican \\
\hline PI 387865 & W-941 d & Bolivia & Andean \\
\hline CNF 0011228 & G2486 & Mexico & Mesoamerican \\
\hline CNF 0011026 & G10966 & Mexico & Mesoamerican \\
\hline CNF 0011137 & G21178 & Mexico & Mesoamerican \\
\hline CNF 0011075 & G9026 & USA & Mesoamerican \\
\hline CNF 0011095 & G148 & USA & Mesoamerican \\
\hline CNF 0011240 & G10843 & Guatemala & Mesoamerican \\
\hline CNF 0011028 & G19497 & Peru & Andean \\
\hline PI 325750 & G19187 & Mexico & Mesoamerican \\
\hline PI 313633 & Narino 47 & Colombia & Andean \\
\hline CNF 0011086 & G2445 & Mexico & Mesoamerican \\
\hline CNF 0011102 & G23840 & Mexico & Mesoamerican \\
\hline CNF 0011015 & G6861 & Honduras & Mesoamerican \\
\hline PI 312031 & G2352 and G6745 & Mexico & Mesoamerican \\
\hline CNF 0011252 & G22647 & Congo & Andean \\
\hline PI 309701 & G18934 and G18934A & Mexico & Mesoamerican \\
\hline CNF 0011027 & G19036 & Mexico & Mesoamerican \\
\hline CNF 0010996 & G10436 & Portugal & Andean \\
\hline CNF 0011053 & G5725 & Mexico & Mesoamerican \\
\hline CNF 0011097 & G2276B & Mexico & Andean \\
\hline PI 313495 & Negro Brilhante & Mexico & Andean \\
\hline CNF 0011451 & & & \\
\hline
\end{tabular}

role of the host genotypes in the process of biological $\mathrm{N}_{2}$ fixation. Therefore, the diversity in genebanks should be intensively exploited towards achieving an improved contribution of symbiotic $\mathrm{N}$ to common bean crop. In common bean breeding programs, the evaluation across different seasons and years is very important for identifying the most stable genotypes (Pereira et al., 2011; Torga et al., 2013). Henceforth, the insertion of the most promising genotypes identified in the present work into specific breeding programs would require field experiments, in order to assess their agronomic performance and stability. Considering the predominant Mesoamerican genetic basis of the Brazilian cultivars (Blair et al., 2013), the difficulty of crossings between the two gene pools (Moreto et al., 2012), and the nodulation stability of Mesoamerican materials observed in this work, crosses between genotypes of Mesoamerican origin seem more advisable for enhancing nodulation of Brazilian common bean cultivars.

\section{Conclusions}

1. There is a large variability in nodulation traits among the common bean genotypes of the Andean and Mesoamerican gene pools, present in core germplasm collections of Embrapa Arroz e Feijão, with many genotypes showing a higher nodulation than the reference cultivar 'Ouro Negro'.

2. Genotypes of the Mesoamerican gene pool show a higher nodule dry weight than those of the Andean gene pool, and should be prioritized in breeding efforts to enhance nodulation of common bean cultivars.

\section{Acknowledgments}

To Empresa Brasileira de Pesquisa Agropecuária (Embrapa, Protocol No. 21161.000167/2016-73), for financing the doctoral studies of the first author. 


\section{References}

ACOSTA-GALLEGOS, J.A.; KELLY, J.D.; GEPTS, P. Prebreeding in common bean and use of genetic diversity from wild germoplasm. Crop Science, v.47, p.S44-S59, 2007. Supplement 3. DOI: 10.2135/cropsci2007.04.0008IPBS.

AKTER, Z.; PAGENI, B.B.; LUPWAYI, N.Z.; BALASUBRAMANIAN, P.M. Biological nitrogen fixation and nif $\mathrm{H}$ gene expression in dry beans (Phaseolus vulgaris L.). Canadian Journal of Plant Science, v.94, p.203-212, 2014. DOI: 10.4141/CJPS2013-200.

ARAÚJO, A.P.; TEIXEIRA, M.G.; ALMEIDA, D.L. de. Variability of traits associated with phosphorus efficiency in wild and cultivated genotypes of common bean. Plant and Soil, v.203, p.173-182, 1998. DOI: 10.1023/a:1004398930218.

ARTHIKALA, M.-K.; SÁNCHEZ-LÓPEZ, R.; NAVA, N.; SANTANA, O.; CÁRDENAS, L.; QUINTO, C. RbohB, a Phaseolus vulgaris NADPH oxidase gene, enhances symbiosome number, bacteroid size, and nitrogen fixation in nodules and impairs mycorrhizal colonization. New Phytologist, v.202, p.886900, 2014. DOI: 10.1111/nph.12714.

BITOCCHI, E.; BELLUCCI, E.; GIARDINI, A.; RAU, D.; RODRIGUEZ, M.; BIAGETTI, E.; SANTILOCCHI, R.; ZEULI, P.S.; GIOIA, T.; LOGOZZO, G.; ATTENE, G.; NANNI, L.; PAPA, R. Molecular analysis of the parallel domestication of the common bean (Phaseolus vulgaris L.) in Mesoamerica and the Andes. New Phytologist, v.197, p.300-313, 2013. DOI: 10.1111/j.1469-8137.2012.04377.x.

BLAIR, M.W.; BRONDANI, R.V.P.; DÍAZ, L.M.; DEL PELOSO, M.J. Diversity and population structure of common bean from Brazil. Crop Science, v.53, p.1983-1993, 2013. DOI: 10.2135/ cropsci2012.09.0516.

BLAIR, M.W.; GONZÁLEZ, L.F.; KIMANI, P.M.; BUTARE, L. Genetic diversity, inter-gene pool introgression and nutritional quality of common beans (Phaseolus vulgaris L.) from Central Africa. Theoretical and Applied Genetics, v.121, p.237-248, 2010. DOI: 10.1007/s00122-010-1305-X.

BURLE, M.L.; FONSECA, J.R.; KAMI, J.A.; GEPTS, P. Microsatellite diversity and genetic structure among common bean (Phaseolus vulgaris L.) landraces in Brazil, a secondary center of diversity. Theoretical and Applied Genetics, v.121, p.801-813, 2010. DOI: 10.1007/s00122-010-1350-5.

DREVON, J.-J.; ALKAMA, N.; ARAUJO, A.; BEEBE, S.; BLAIR, M.W.; HAMZA, H.; JAILLARD, B.; LOPEZ, A.; MARTINEZ-ROMERO, E.; RODINO, P.; TAJINI, F.; ZAMANALLAH, M. Nodular diagnosis for ecological engineering of the symbiotic nitrogen fixation with legumes. Procedia Environmental Sciences, v.9, p.40-46, 2011. DOI: 10.1016/j. proenv.2011.11.008.

FAGERIA, N.K.; MELO, L.C.; FERREIRA, E.P.B.; OLIVEIRA, J.P.; KNUPP, A.M. Dry matter, grain yield, and yield components of dry bean as influenced by nitrogen fertilization and rhizobia. Communications in Soil Science and Plant Analysis, v.45, p.111-125, 2014. DOI: 10.1080/00103624.2013.848877.
FARID, M.; NAVABI, A. $\mathrm{N}_{2}$ fixation ability of different dry bean genotypes. Canadian Journal of Plant Science, v.95, p.12431257, 2015. DOI: 10.4141/CJPS-2015-084.

GAUT, B.S. The complex domestication history of the common bean. Nature Genetics, v.46, p.663-664, 2014. DOI: 10.1038/ ng.3017.

GRAHAM, P.H.; ROSAS, J.C.; ESTEVEZ de JENSEN, C.; PERALTA, E.; TLUSTY, B.; ACOSTA-GALlEGOS, J.; ARRAES PEREIRA, P.A. Addressing edaphic constraints to bean production: the Bean/Cowpea CRSP project in perspective. Field Crops Research, v.82, p.179-192, 2003. DOI: 10.1016/ S0378-4290(03)00037-6.

HANNAH, M.A.; KRÄMER, K.M.; GEFFROY, V.; KOPKA, J.; BLAIR, M.W.; ERBAN, A.; VALLEJOS, C.E.; HEYER, A.G.; SANDERS, F.E.T.; MILLNER, P.A.; PILBEAM, D.J. Hybrid weakness controlled by the dosage-dependent lethal (DL) gene system in common bean (Phaseolus vulgaris) is caused by a shootderived inhibitory signal leading to salicylic acid-associated root death. New Phytologist, v.176, p.537-549, 2007. DOI: 10.111/ j1469-8137.2007.02215.x.

HENSON, R.A.; PEREIRA, P.A.A.; CARNEIRO; J.E.S.; BLISS, F.A. Registration of 'Ouro Negro', a high dinitrogen-fixing, highyielding common bean. Crop Science, v.33, p.644, 1993.

KRAISER, T.; GRAS, D.E.; GUTIÉRREZ, A.G.; GONZÁLEZ, B.; GUTIÉRREZ, R.A. A holistic view of nitrogen acquisition in plants. Journal of Experimental Botany, v.62, p.1455-1466, 2011. DOI: $10.1093 / \mathrm{jxb} / \mathrm{erq} 425$.

LAZALI, M.; BRAHIMI, S.; MERABET, C.; LATATI, M.; BENADIS, C.; MAOUGAL, R.T.; BLAVET, D.; DREVON, J.J.; OUNANE, S.M. Nodular diagnosis of contrasting recombinant inbred lines of Phaseolus vulgaris in multi-local field tests under Mediterranean climate. European Journal of Soil Biology, v.73, p.100-107, 2016. DOI: 10.1016/j.ejsobi.2016.02.002.

MORETO, A.L.; RAMALHO, M.A.P.; BRUZI, A.T. Epistasis in an Andean x Mesoamerican cross of common bean. Euphytica, v.186, p.755-760, 2012. DOI: 10.1007/s10681-011-0578-8.

PEREIRA, H.S.; MELO, L.C.; DEL PELOSO, M.J.; FARIA, L.C. de; WENDLAND, A. Complex interaction between genotypes and growing seasons of carioca common bean in Goiás/Distrito Federal. Crop Breeding and Applied Biotechnology, v.11, p.207-215, 2011. DOI: 10.1590/S1984-70332011000300002.

PEREIRA, P.A.A.; MIRANDA, B.D.; ATTEWELL, J.R.; KMIECIK, K.A.; BLISS, F.A. Selection for increased nodule number in common bean (Phaseolus vulgaris L.). Plant and Soil, v.148, p.203-209, 1993. DOI: 10.1007/BF00012858.

RANA, J.C.; SHARMA, T.R.; TYAGI, R.K.; CHAHOTA, R.K.; GAUTAM, N.K.; SINGH, M.; SHARMA, P.N.; OJHA, S.N. Characterisation of 4274 accessions of common bean (Phaseolus vulgaris L.) germplasm conserved in the Indian gene bank for phenological, morphological and agricultural traits. Euphytica, v.205, p.441-457, 2015. DOI: 10.1007/s10681-015-1406-3.

RODIÑO, A.P.; DE LA FUENTE, M.; DE RON, A.M.; LEMA, M.J.; DREVON, J.J.; SANTALLA, M. Variation for nodulation and plant yield of common bean genotypes and environmental 
effects on the genotype expression. Plant and Soil, v.346, p.349361, 2011. DOI: 10.1007/s11104-011-0823-x.

SANTOS, M.A.; GERALDI, I.O.; GARCIA, A.A.F.; BORTOLATTO, N.; SCHIAVON, A.; HUNGRIA, M. Mapping of QTLs associated with biological nitrogen fixation traits in soybean. Hereditas, v.150, p.17-25, 2013. DOI: 10.1111/j.16015223.2013.02275.x.

SINGH, S.P. Broadening the genetic base of common bean cultivars: a review. Crop Science, v.41, p.1659-1675, 2001. DOI: 10.2135/cropsci2001.1659.

SINGH, S.P.; GEPTS, P.; DEBOUCK, D.G. Races of common bean (Phaseolus vulgaris, Fabaceae). Economic Botany, v.45, p.379-396, 1991. DOI: 10.1007/BF02887079.
TERÁN, H.; SINGH, S.P. Efficacy of three greenhouse screening methods for the identification of physiological resistance to white mold in dry bean. Canadian Journal of Plant Science, v.89, p.755-762, 2009. DOI: 10.4141/CJPS08230.

TORGA, P.P.; MELO, P.G.S.; PEREIRA, H.S.; FARIA, L.C. de; DEL PELOSO, M.J.; MELO, L.C. Interaction of common beans cultivars of the black group with years, locations and sowing seasons. Euphytica, v.189, p.239-248, 2013. DOI: 10.1007/s10681012-0793-y.

VINCENT, J.M. A manual for the practical study of the rootnodule bacteria. London: International Biological Programme, 1970. 164p. (IBP. Handbook, 15).

Received on August 25, 2016 and accepted on February 17, 2017 